\title{
Association of whole grains intake and the risk of digestive tract cancer: a systematic review and meta-analysis
}

\author{
Xiao-Feng Zhang ${ }^{1}$, Xiao-Kai Wang ${ }^{1}$, Yu-Jun Tang ${ }^{1}$, Xiao-Xian Guan ${ }^{1}$, Yao Guo², Jian-Ming Fan¹ and \\ Ling-Ling Cui ${ }^{1 *}$ (D)
}

\begin{abstract}
Background: Several epidemiological studies have investigated the association between whole grains intake and digestive tract cancer risk; however, the results are still controversial. The purpose of this meta-analysis was to assess the association.

Methods: Studies published before March 2020 were searched in database and other sources. The risk ratio (RR) with the $95 \%$ confidence interval (Cl) were pooled using fix or random-effects models.

Results: This meta-analysis included 34 articles reporting 35 studies, 18 studies of colorectal cancer, 11 studies of gastric cancer and 6 studies of esophagus cancer, involving 2,663,278 participants and 28,921 cases. Comparing the highest-intake participants with the lowest-intake participants for whole grains, we found that the intake of whole grains were inversely related to colorectal cancer $(R R=0.89,95 \% \mathrm{Cl}: 0.84-0.93, P<0.001)$, gastric cancer $(\mathrm{RR}=0.64,95 \%$ Cl: $0.53-0.79, P<0.001)$, esophagus cancer ( $R R=0.54,95 \% \mathrm{Cl}: 0.44-0.67, P<0.001)$, respectively. However, subgroup analysis of colorectal cancer found no significant association in the case-control studies and studies of sample size $<500$, and subgroup analysis of gastric cancer found no significant association in the cohort studies and studies of American population. No study significantly affected the findings in the sensitivity analysis. No publication bias was found in the studies for colorectal cancer and esophagus cancer except in the studies for gastric cancer.

Conclusion: This meta-analysis provides further evidence that whole grains intake was associated with a reduced risk of digestive tract cancer. Our result supports the dietary guidelines that increase whole grains intake to reduce the risk of digestive tract cancer.
\end{abstract}

Keywords: Whole grains, Digestive tract cancer, Colorectal cancer, Gastric cancer, Esophagus cancer, Meta-analysis

\section{Background}

Globally, digestive tract cancer are common type of cancer. The global cancer statistics 2018 shows that the incidence of colorectal cancer, gastric cancer and esophageal cancer ranks third, fifth and seventh, and the mortality ranks second, third and sixth among all cancers,

\footnotetext{
* Correspondence: cll@zzu.edu.cn

'Department of Nutrition and Food Hygiene, College of Public Health, Zhengzhou University, 100 Kexue Avenue, Zhengzhou 450001, Henan, China Full list of author information is available at the end of the article
}

respectively [1]. Digestive tract cancer has become one of the major diseases that threaten human health. The occurrence of digestive tract cancer is related a variety of factors, of which approximately $5-10 \%$ can be attributed to genetic defects, whereas and the remaining $90-95 \%$ can be explained by unfavorable environment conditions or an unhealthy lifestyle [2,3]. Studies have shown that diet plays an important role in the digestive tract cancer risk [4-6]. Grains are key components of the diet and supply much of the world's energy and nutrient needs. They

(c) The Author(s). 2020 Open Access This article is licensed under a Creative Commons Attribution 4.0 International License, which permits use, sharing, adaptation, distribution and reproduction in any medium or format, as long as you give appropriate credit to the original author(s) and the source, provide a link to the Creative Commons licence, and indicate if changes were made. The images or other third party material in this article are included in the article's Creative Commons licence, unless indicated otherwise in a credit line to the material. If material is not included in the article's Creative Commons licence and your intended use is not permitted by statutory regulation or exceeds the permitted use, you will need to obtain permission directly from the copyright holder. To view a copy of this licence, visit http://creativecommons.org/licenses/by/4.0/ The Creative Commons Public Domain Dedication waiver (http://creativecommons.org/publicdomain/zero/1.0/) applies to the data made available in this article, unless otherwise stated in a credit line to the data. 
make up the largest proportion of recommended daily food intake $[7,8]$. Due to their important role in most diets in the world, there was a lot of research on the relationship between grains consumption and health. With the development of grains research, the health function of whole grains food has been confirmed and aroused people's interest [9]. Whole grains consist of the intact, ground, cracked, or flaked kernel after the removal of inedible parts. The principal anatomical components, the starchy endosperm, germ, and bran, are present in the same relative proportions as they exist in the intact kernel [10]. Compared to refined grains, whole grains are rich in dietary fiber and a variety of phytochemicals, which play an important role in preventing chronic diseases. Several studies have found a lower risk of obesity [11], cardiovascular disease [12, 13], type 2 diabetes [14], coronary heart disease $[8,15]$, stroke [8], cancer $[13,16]$ associated with a higher intake of whole grains.

A previous review of mostly case-control studies showed higher whole grains intake was associated with lower risk of several individual cancers, mainly of the digestive system [17], but limited data from cohort studies. Several epidemiological studies have investigated the relationship between whole grains intake and digestive tract cancer risk. However, these results are controversial. In 2003, Cullouh et al. reported that a statistically non-significant $17 \%$ increase in colon cancer risk was observed for women with the higher whole grains intakes [18]. However, in 2006, McCarl et al. report that that higher whole grains intake can reduce the risk of colorectal cancer by $19 \%$ for women [19]. In 2004, Lissowska et al. report that their study do not support a protective effect of whole grains for gastric cancer [20]. However, in 2002, Kasum et al. report that intake of whole grains was associated with reduced risk of upper aerodigestive tract cancers, including oropharyngeal, laryngeal, salivary, esophageal and gastric cancers [21]. From a public health perspective, it is important to clarify this issue. Therefore, the purpose of this meta-analysis was to determine whether there is an association between whole grains intake and digestive tract cancer.

\section{Methods}

\section{Search strategy}

Studies published before March 2020 were searched in database and other sources. In order to avoid missing any relevant research, we also searched the bibliography of the retrieved papers. The following keywords were used in the literature search: "grains" or "cereal" or "wheat" or "corn" or "rye" or "oats" or "oatmeal" or "bread" or "barley" or "bran" or "germ" or "colorectal cancer" or "colon cancer" or "rectal cancer" or "CRC" or "colorectal carcinoma" or "gastric cancer" or "stomach cancer" or "esophagus cancer" or "esophageal squamous cell carcinoma". No restrictions were imposed.

\section{Study selection}

Studies were considered for inclusion if they met the following criteria: (1) the research was a cohort study or a case-control study. (2) The research assessed the association between whole grains intake and the risk of colorectal cancer, esophageal cancer and gastric cancer. (3) The RR or odds ratios (OR) estimates with $95 \%$ confidence were reported or could be calculated. If data were duplicated in more than one study, the one with the largest number of cases or the longest follow-up period was included in the meta-analysis.

\section{Data extraction}

Two independent researchers carried out an initial assessment of obtained literature to exclude those failing to meet the inclusion criteria. A further full-text assessment of the studies that had the potential to meet the criteria was made, and any disagreements were resolved by discussion between two authors or by the third investigator. Data extracted from each study included: the first author's name, year of publication, country, cancer site, study design, diet assessment, simple (case), intake of whole grains, RR (OR) with 95\%CI and variables adjusted.

\section{Quality assessment}

The included case-control and cohort studies were assessed by two investigators using the scoring system of the Newcastle-Ottawa scale (NOS) [22]. The highest score was 9 points, and those with a score 7 were classified as high-quality literatures.

\section{Statistical analysis}

Statistical analysis was performed using STATA version 12.0. The results were expressed as RR and 95\% CI to measure the association between whole grains intake and the risk of digestive tract cancer. The heterogeneity assumption was examined by a Chi-square test based on a Q-test. Generally, $I^{2}$ statistics of 25,50 , and $75 \%$ indicate low, moderate, and high levels of heterogeneity, respectively. If $p<0.05$ and/or $I^{2}>50 \%$, a random-effect model based was used to calculate pooled (RR) with the 95\% confidence interval (CI). Otherwise, a fixed-effect model was used. Due to characteristics of participants, and adjustments for confounding factors were not consistent across studies, we further conducted several sensitivity and subgroup analyses to explore possible sources of heterogeneity and to examine the influence of various factors on the overall risk estimate. Sensitivity analysis was conducted by omitting one study each time and recalculating the pooled RR. Finally, we applied Begg's method to assess bias. 


\section{Results}

Literature search and study characteristics

A flowchart of the research selection process of this metaanalysis is shown in Fig. 1. The search of database and other sources identified 1679 potentially relevant articles after duplicate exclusion. In addition, 1645 articles were excluded after further evaluations. Finally, 34 [18-21, 23-52] articles reporting 35 studies were selected for this meta-analysis.

Table 1 summarizes the general characteristics of these studies. All included studies were of high quality literature with scores greater than 7 points. Of the 35 studies, 14 were cohort studies and 22 were case-control studies, which included a total of 2663.278 participants and 28,921 cases. These studies were adjusted for a wide range of potential confounding factors, including age, sex, education, smoking, BMI, income, physical activity, energy intake, alcohol intake, red and processed meat intake etc.

Whole grains intake and overall digestive tract cancer risk As shown in Fig. 2, 35 studies including 266,378 participants and 28,921 case. Were selected for the analysis of whole grains

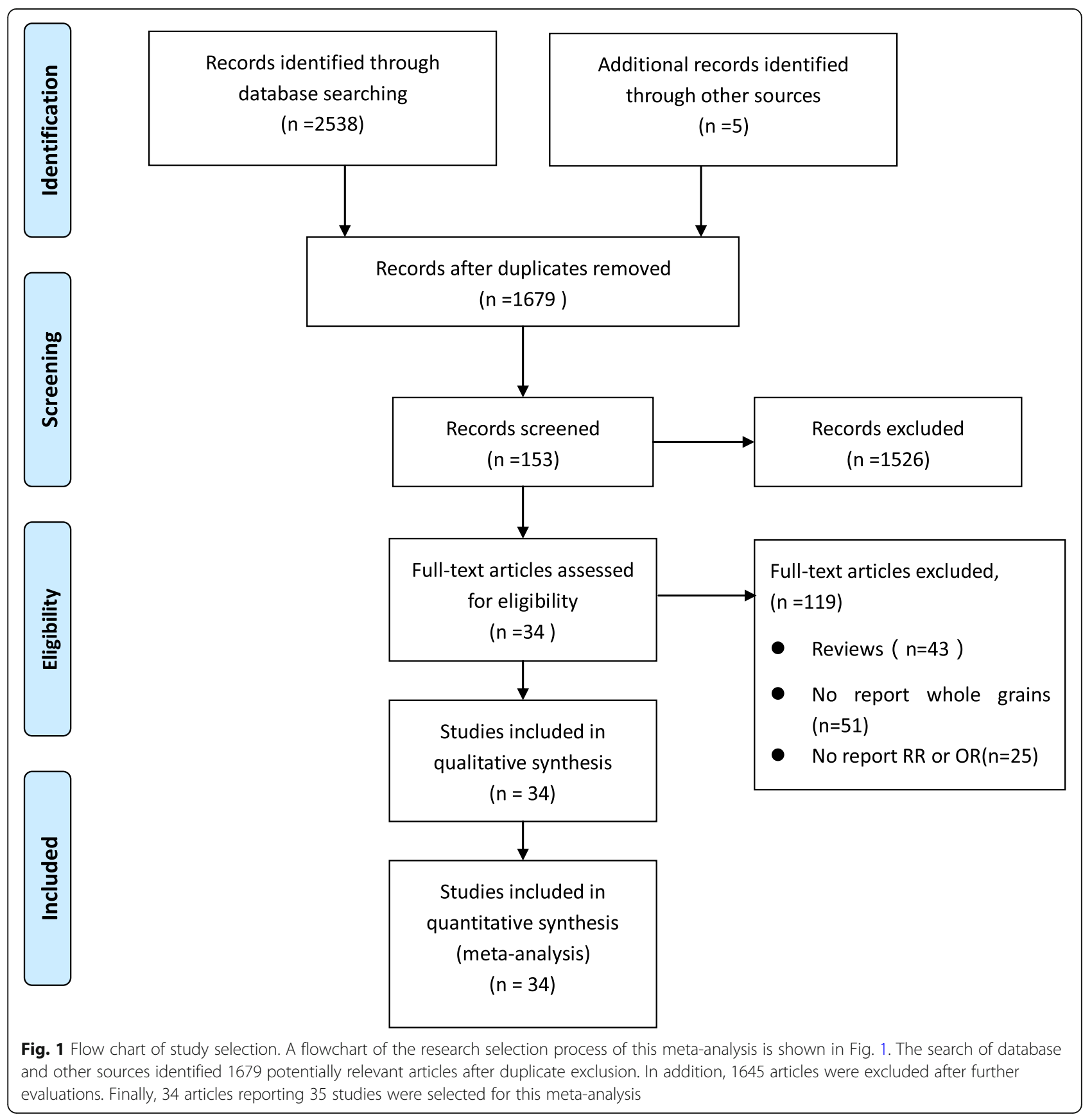




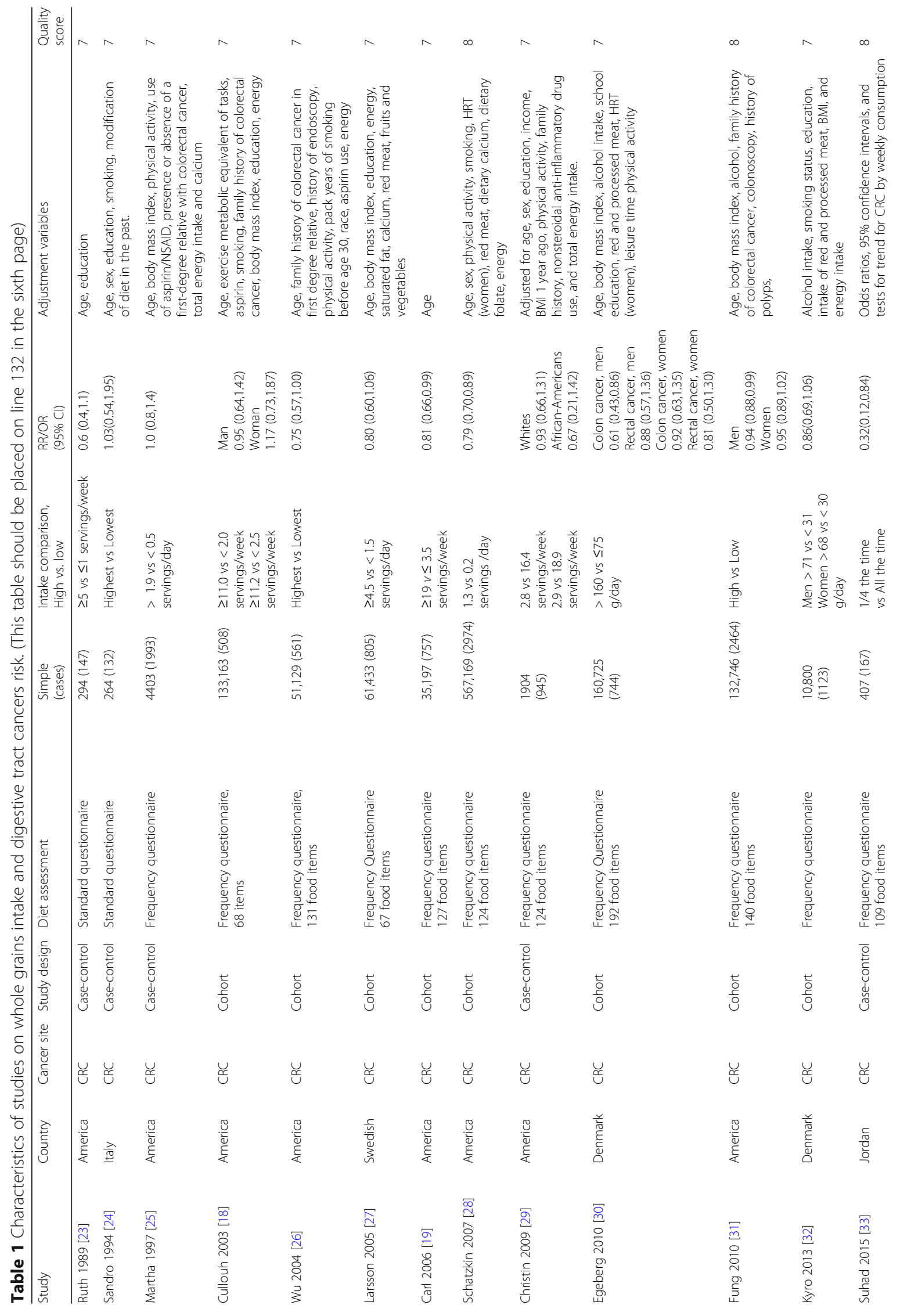




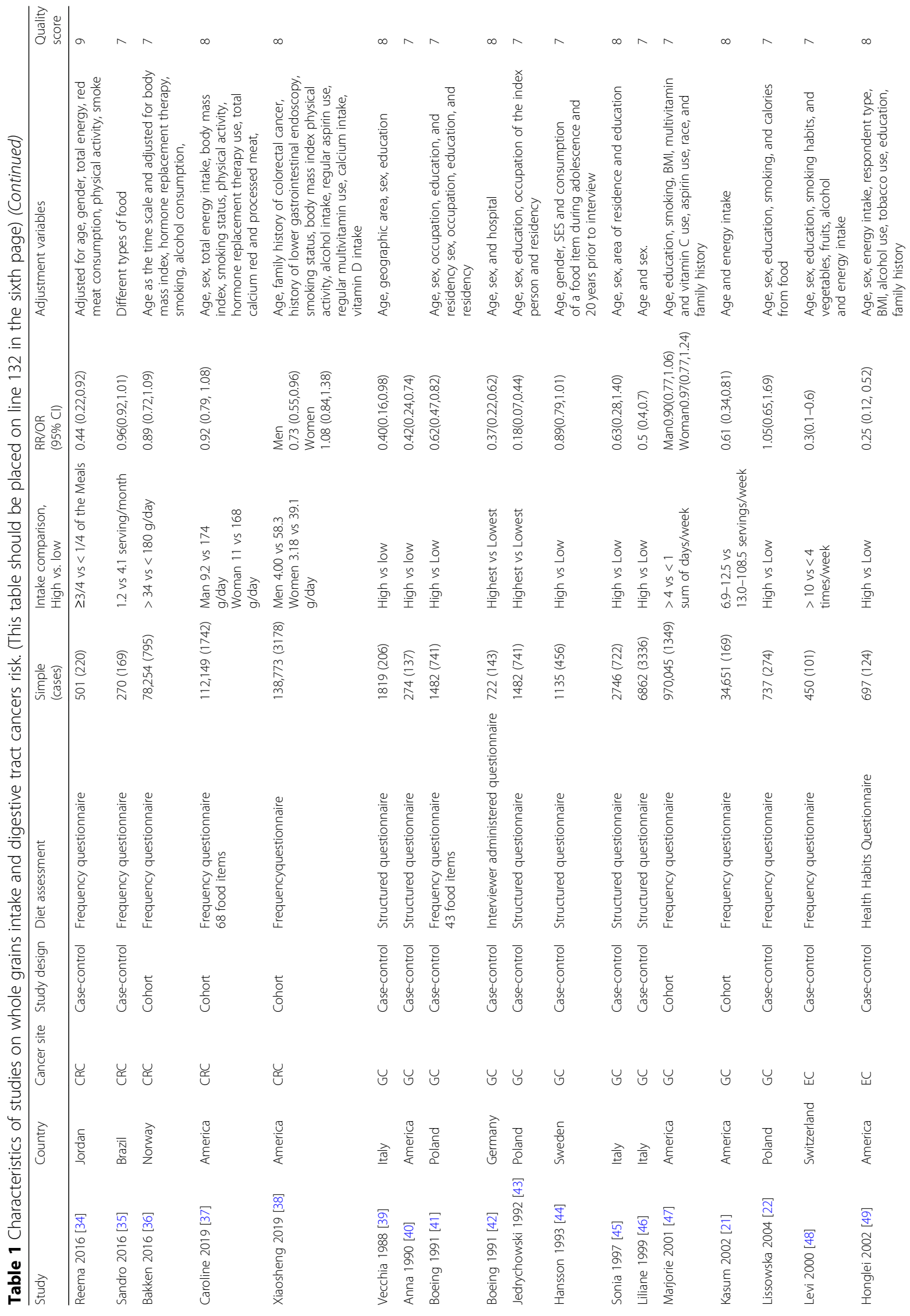




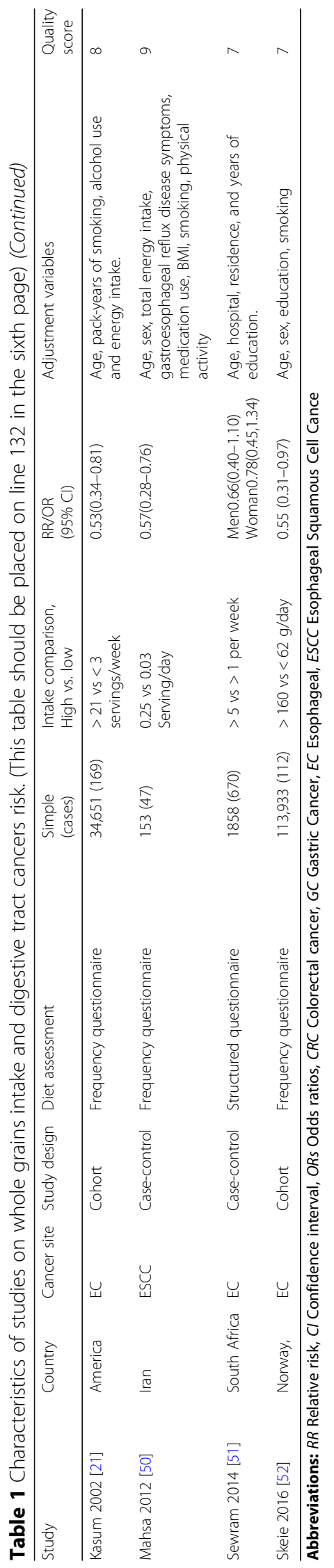




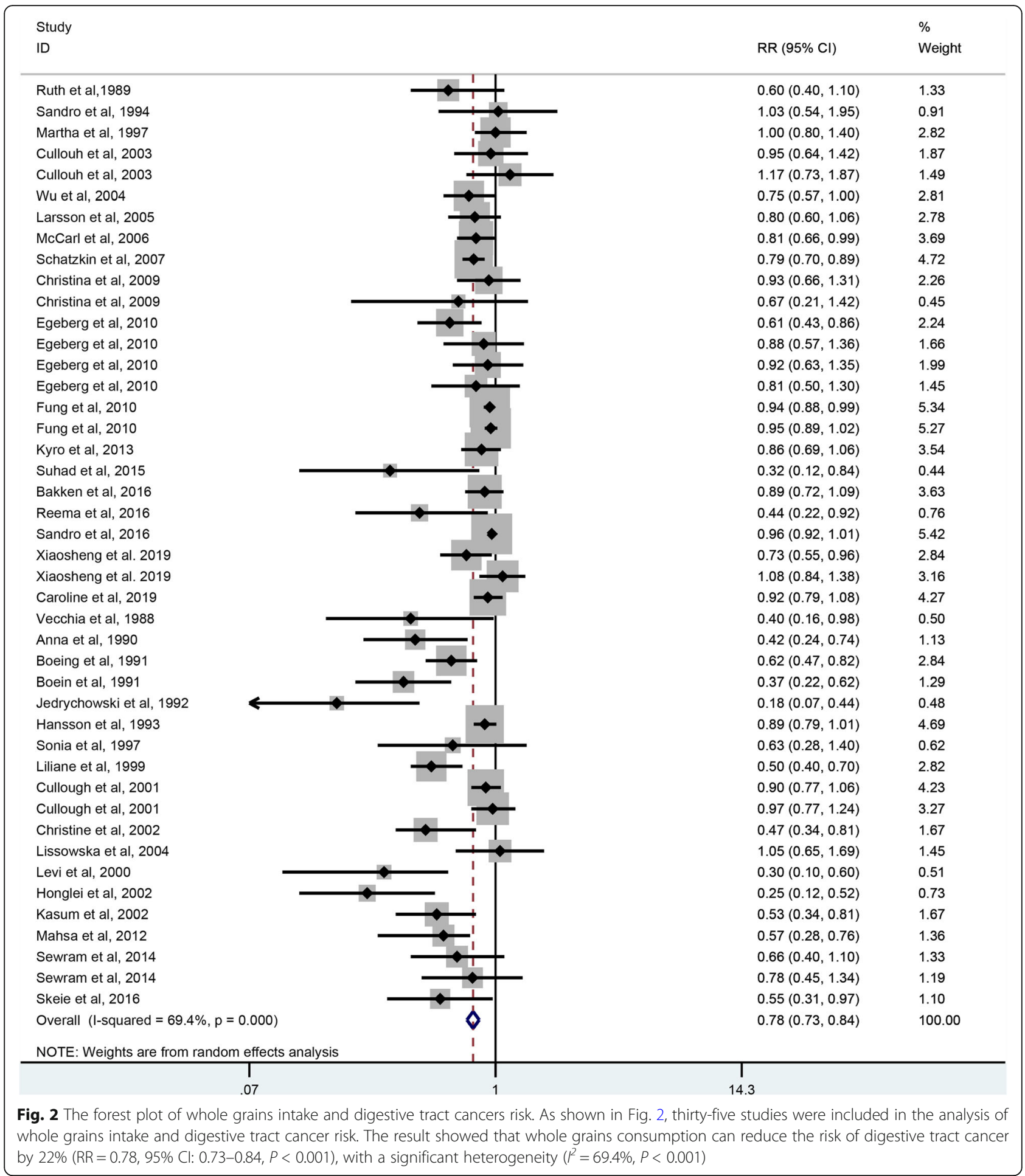

intake and digestive tract cancer risk. The result showed that whole grains consumption can reduce the risk of digestive tract cancer by $22 \%(\mathrm{RR}=0.78,95 \% \mathrm{CI}: 0.73-0.84, P<0.001)$, with a significant heterogeneity $\left(I^{2}=69.4 \%, P<0.001\right)$.
Whole grains intake and colorectal cancer risk

As shown in Fig. 3, 18 studies including 1,489,581 participants and 19,424 case were selected for the analysis of whole grains intake and colorectal cancer risk. The 


\begin{tabular}{|c|c|c|}
\hline $\begin{array}{l}\text { Study } \\
\text { ID }\end{array}$ & $\mathrm{RR}(95 \% \mathrm{Cl})$ & $\begin{array}{l}\% \\
\text { Weight }\end{array}$ \\
\hline Ruth et al,1989 & $0.60(0.40,1.10)$ & 0.97 \\
\hline Sandro et al, 1994 & $1.03(0.54,1.95)$ & 0.62 \\
\hline Martha et al, 1997 & $1.00(0.80,1.40)$ & 2.82 \\
\hline Cullouh et al, 2003 & $0.95(0.64,1.42)$ & 1.52 \\
\hline Cullouh et al, 2003 & $1.17(0.73,1.87)$ & 1.11 \\
\hline Wu et al, 2004 & $0.75(0.57,1.00)$ & 2.80 \\
\hline Larsson et al, 2005 & $0.80(0.60,1.06)$ & 2.74 \\
\hline McCarl et al, 2006 & $0.81(0.66,0.99)$ & 4.69 \\
\hline Schatzkin et al, 2007 & $0.79(0.70,0.89)$ & 8.95 \\
\hline Christina et al, 2009 & $0.93(0.66,1.31)$ & 1.99 \\
\hline Christina et al, 2009 & $0.67(0.21,1.42)$ & 0.28 \\
\hline Egeberg et al, 2010 & $0.61(0.43,0.86)$ & 1.95 \\
\hline Egeberg et al, 2010 & $0.88(0.57,1.36)$ & 1.29 \\
\hline Egeberg et al, 2010 & $0.92(0.63,1.35)$ & 1.64 \\
\hline Egeberg et al, 2010 & $0.81(0.50,1.30)$ & 1.08 \\
\hline Fung et al, 2010 & $0.94(0.88,0.99)$ & 14.25 \\
\hline Fung et al, 2010 & $0.95(0.89,1.02)$ & 13.39 \\
\hline Kyro et al, 2013 & $0.86(0.69,1.06)$ & 4.31 \\
\hline Suhad et al, $2015 \leftarrow$ & $0.32(0.12,0.84)$ & 0.27 \\
\hline Reema et al, 2016 & $0.44(0.22,0.92)$ & 0.50 \\
\hline Sandro et al, 2016 & $0.96(0.92,1.01)$ & 15.32 \\
\hline Bakken et al, 2016 & $0.89(0.72,1.09)$ & 4.54 \\
\hline Xiaosheng et al. 2019 & $0.73(0.55,0.96)$ & 2.84 \\
\hline Xiaosheng et al. 2019 & $1.08(0.84,1.38)$ & 3.44 \\
\hline Caroline et al, 2019 & $0.92(0.79,1.08)$ & 6.67 \\
\hline Overall $(\mathrm{I}-$ squared $=38.2 \%, \mathrm{p}=0.029)$ & $0.89(0.84,0.93)$ & 100.00 \\
\hline \multicolumn{3}{|l|}{ NOTE: Weights are from random effects analysi\$ } \\
\hline 12 & & \\
\hline
\end{tabular}

result showed that whole grains consumption reduced the risk of colorectal cancer by $11 \%(\mathrm{RR}=0.89,95 \% \mathrm{CI}$ : 0.84-0.93, $P<0.001)$, with a slight heterogeneity $\left(I^{2}=\right.$ $38.2 \%, P=0.029$ ).

There is a slight heterogeneity existed across the studies of whole grains intake and colorectal cancer risk and subgroup analysis were performed to find the source of heterogeneity. As shown in Table 2, the subgroup analysis was conducted according to the study design, sex, geographic location, publication year, sample size and whether adjust for energy intake. The result indicated that whole grains intake was protective factor for the studies of sample size $\geq 500$ (RR: 0.91 , 95\% CI: $0.88-0.94, P<0.001$ ), but no significant association was found in the studies of sample size < 500 (RR: 0.76, 95\% CI: 0.51-1.12, $P=0.170$ ). In the subgroup analysis of sex, geographic location, publication year and whether adjust for energy intake, no statistically significant heterogeneity was found in the studies of women $\left(I^{2}=0 \%, P=0.619\right)$, studies of Europe $\left(I^{2}=0 \%\right.$, $P=0.732)$, studies of publication year before $2010\left(I^{2}=\right.$ $0 \%, P=0.622)$, studies of adjustment for energy $\left(I^{2}=4.6 \%\right.$, $P=0.399)$.

\section{Whole grains intake and gastric cancer risk}

As shown in Fig. 4, 11 studies including 1,021,955 participants and 8274 case were selected for the analysis of whole grains intake and gastric cancer risk. The result showed that whole grains consumption reduced the risk 
Table 2 Subgroup analysis of whole grains intake and risk of colorectal cancer

\begin{tabular}{|c|c|c|c|c|c|c|c|}
\hline \multirow[t]{2}{*}{ Subgroups } & \multirow{2}{*}{$\begin{array}{l}\text { No. of } \\
\text { studies }\end{array}$} & \multirow{2}{*}{$\begin{array}{l}\text { No. of } \\
\text { Participants } \\
\text { (Cases) }\end{array}$} & \multirow[t]{2}{*}{ RR $(95 \%$ Cl) } & \multirow[t]{2}{*}{$P$} & \multicolumn{3}{|c|}{ Heterogeneity Test } \\
\hline & & & & & Chi-Square & $I^{2}$ & $p_{\text {het }}$ \\
\hline All studies & 18 & $1,489,581(19424)$ & $0.89(0.84,0.93)$ & $<0.001$ & 38.82 & $38 \%$ & 0.029 \\
\hline \multicolumn{8}{|l|}{ Study design } \\
\hline Cohort & 11 & $1,481,538(15519)$ & $0.91(0.88,0.94)$ & $<0.001$ & 22.95 & $30.3 \%$ & 0.115 \\
\hline Case-control & 7 & 8043(3905) & $0.95(0.91,1.00)$ & 0.030 & 13.33 & $47.5 \%$ & 0.064 \\
\hline \multicolumn{8}{|l|}{ Sex } \\
\hline Men & 7 & $236,055(4826)$ & $0.80(0.69,0.92)$ & 0.001 & 14.07 & $50.3 \%$ & 0.050 \\
\hline Women & 8 & $454,822(7126)$ & $0.94(0.89,0.99)$ & $<0.001$ & 6.25 & $0 \%$ & 0.619 \\
\hline \multicolumn{8}{|c|}{ Geographic locations } \\
\hline Europe & 5 & $311,476(3599)$ & $0.84(0.75,0.93)$ & 0.001 & 4.40 & $0 \%$ & 0.732 \\
\hline America & 10 & $1,176,927(15769)$ & $0.92(0.88,0.95)$ & $<0.001$ & 19.83 & $34.5 \%$ & 0.099 \\
\hline \multicolumn{8}{|c|}{ Publication year } \\
\hline Before 2010 & 9 & $854,956(8822)$ & $0.82(0.76,0.89)$ & $<0.001$ & 8.07 & $0 \%$ & 0.622 \\
\hline After 2010 & 9 & $634,625(10602)$ & $0.94(0.91,0.97)$ & $<0.001$ & 21.73 & $40.2 \%$ & 0.060 \\
\hline \multicolumn{8}{|l|}{ Sample size } \\
\hline$\geq 500$ & 14 & $1,488,346(18809)$ & $0.91(0.88,0.94)$ & $<0.001$ & 27.76 & $27.9 \%$ & 0.115 \\
\hline$<500$ & 4 & $1235(615)$ & $0.76(0.51,1.12)$ & 0.170 & 8.20 & $63.4 \%$ & 0.042 \\
\hline \multicolumn{8}{|c|}{ Adjustment for energy } \\
\hline Yes & 9 & $881,482(10198)$ & $0.85(0.79,0.92)$ & $<0.001$ & 10.48 & $4.6 \%$ & 0.399 \\
\hline No & 9 & 608,299(9226) & $0.94(0.91,0.97)$ & $<0.001$ & 21.84 & $40.5 \%$ & 0.058 \\
\hline
\end{tabular}

of gastric cancer by $36 \%(\mathrm{RR}=0.64,95 \% \mathrm{CI}: 0.53-0.79$, $P<0.001)$, with a significant heterogeneity $\left(I^{2}=78.2 \%\right.$, $P=0.001)$.

There is a significant heterogeneity existed across the studies of whole grains intake and gastric cancer risk and subgroup analysis were performed to find the source of heterogeneity. As shown in Table 3, the subgroup analysis was conducted according to the study design, geographic location, sample size, and whether adjustment for energy. The result indicate that whole grains intake was protective factor for case-control studies $(R R=0.55$, 95\% CI: $0.41-0.74, P<0.001)$ and studies of Europe $(\mathrm{RR}=0.64,95 \% \mathrm{CI}: 0.53-0.79, P<0.001)$, but no significant association was found in cohort studies $(\mathrm{RR}=0.89$, 95\% CI: $0.78-1.01, P=0.070)$ and studies of America (RR $=0.70,95 \% \mathrm{CI}: 0.50-1.00, P=0.051)$. In the subgroup analysis of study design, heterogeneity decreased significantly in the cohort studies $\left(I^{2}=41.7 \%, P=0.180\right)$. However, there was a significant heterogeneity in the case-control studies $\left(I^{2}=80.8 \%, P<0.001\right)$.

\section{Whole grains intake and esophagus cancer risk}

As shown in Fig. 5, 6 studies including 151,742 participants and 1223 case were selected for the analysis of whole grains intake and esophagus cancer risk. The result showed that whole grains consumption reduced the risk of esophagus cancer by $47 \%(\mathrm{RR}=0.54,95 \% \mathrm{CI}$ :
0.44-0.67, $P<0.001)$ with no statistically significant heterogeneity $\left(I^{2}=27.7 \%, P=0.217\right)$.

\section{Sensitivity analysis and publication bias}

Sensitivity analysis suggested that no individual study significantly affected the pooled RR, which indicated that our results were statistically robust. The Begger test indicated no publication bias was found in the studies for colorectal cancer and esophagus cancer except in the studies for gastric cancer.

\section{Discussion}

In this systematic review and meta-analysis, we evaluated the association between whole grains intake and the risk of digestive tract cancer. The results suggest that higher intake of whole grains were associated with lower risk of colorectal cancer, gastric cancer and esophageal cancer.

Previous studies have reported the association between whole grains and digestive tract cancer risk. In 1998 Liliane et al. [17]. first reported the association between whole grains and digestive tract cancer, and the result shows that higher intake of whole grains can reduce the risk of cancer in the colorectal cancer, gastric cancer and esophageal cancer. However, the literatures included in this study are almost case-control studies with limited sample size. In 2011 Dagfinn Aune et al. [16]. reported that a high intake of whole grains was associated with a 


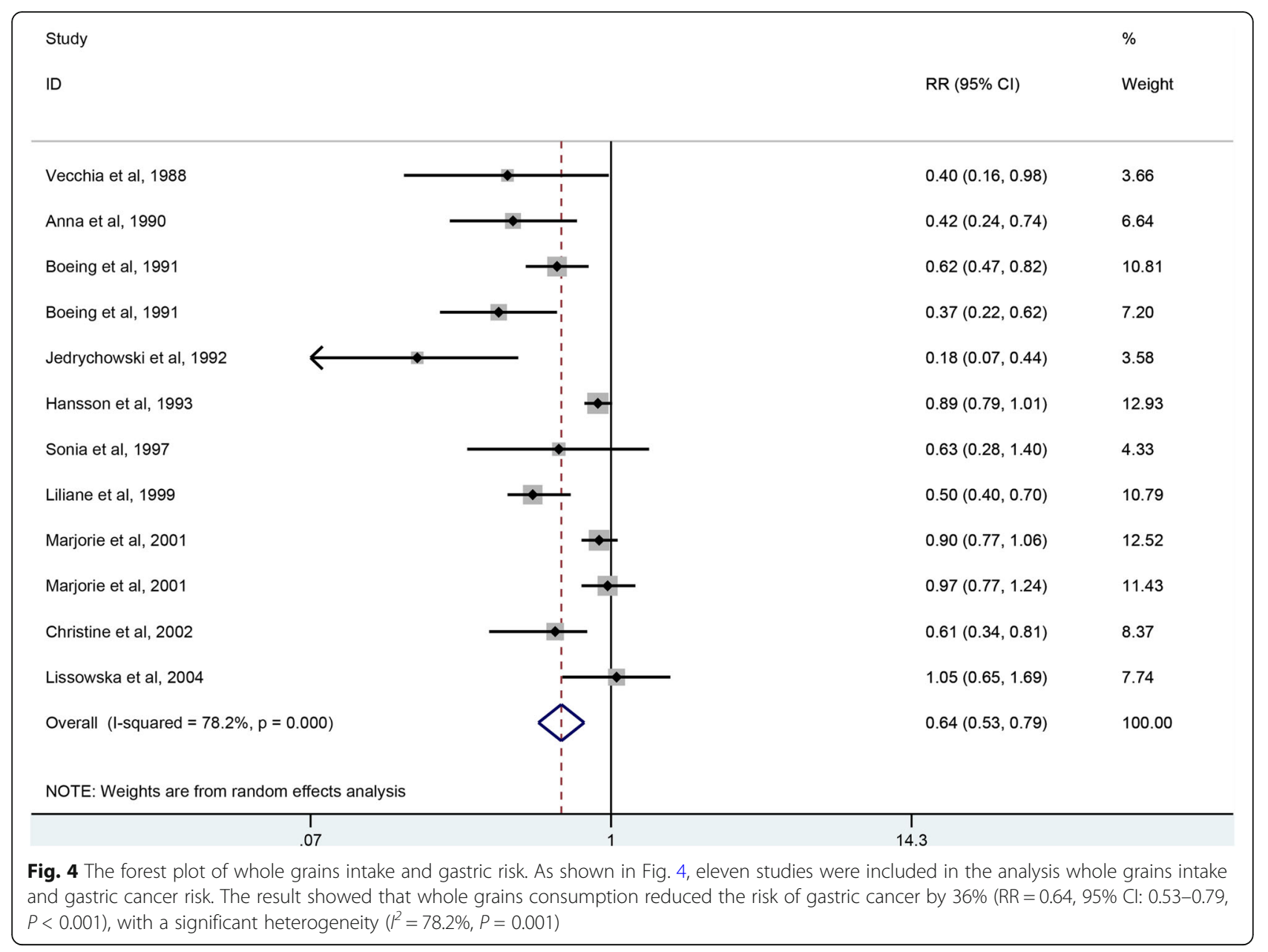

Table 3 Subgroup analysis of whole grains intake and risk of gastric cancer

\begin{tabular}{|c|c|c|c|c|c|c|c|}
\hline \multirow[t]{2}{*}{ Subgroups } & \multirow{2}{*}{$\begin{array}{l}\text { No. of } \\
\text { studies }\end{array}$} & \multirow{2}{*}{$\begin{array}{l}\text { No. of } \\
\text { Participants } \\
\text { (Cases) }\end{array}$} & \multirow[t]{2}{*}{ RR $(95 \%$ Cl) } & \multirow[t]{2}{*}{$P$} & \multicolumn{3}{|c|}{ Heterogeneity Test } \\
\hline & & & & & Chi-Square & $r^{2}$ & $p_{\text {het }}$ \\
\hline All studies & 11 & $1,021,955(8274)$ & $0.64(0.53,0.79)$ & $<0.001$ & 50.42 & $78.2 \%$ & $<0.001$ \\
\hline \multicolumn{8}{|l|}{ Study design } \\
\hline Cohort & 2 & $1,004,696(1518)$ & $0.89(0.78,1.01)$ & 0.070 & 3.43 & $41.7 \%$ & 0.180 \\
\hline Case-control & 9 & $17,259(6756)$ & $0.55(0.41,0.74)$ & $<0.001$ & 41.59 & $80.8 \%$ & $<0.001$ \\
\hline \multicolumn{8}{|c|}{ Geographic locations } \\
\hline Europe & 8 & $16,985(6619)$ & $0.64(0.53,0.79)$ & $<0.001$ & 50.42 & $78.2 \%$ & $<0.001$ \\
\hline America & 3 & $1,004,970(1655)$ & $0.70(0.50,1.00)$ & 0.051 & 9.92 & $69.8 \%$ & 0.019 \\
\hline \multicolumn{8}{|l|}{ Sample size } \\
\hline$\geq 500$ & 10 & $1,021,681(8137)$ & $0.67(0.54,0.82)$ & $<0.001$ & 45.51 & $78.0 \%$ & $<0.001$ \\
\hline$<500$ & 1 & 274(137) & $0.42(0.24,0.74)$ & 0.003 & N/A & N/A & N/A \\
\hline \multicolumn{8}{|c|}{ Adjustment for energy } \\
\hline Yes & 1 & $34,651(169)$ & $0.61(0.34,0.81)$ & 0.026 & N/A & N/A & N/A \\
\hline No & 10 & $987,204(8105)$ & $0.65(0.52,0.80)$ & $<0.001$ & 49.03 & $79.6 \%$ & $<0.001$ \\
\hline
\end{tabular}




$\begin{aligned} & \text { Study } \\ & \text { ID }\end{aligned}$
RR (95\% Cl)

decreased risk of colorectal cancer. In 2017, A. R. Vieira et al. [6]. reported that colorectal cancer risk decrease in $17 \%$ for each $90 \mathrm{~g} /$ day increase of whole grains. In 2018, Yujie $\mathrm{Xu}$ et al. [53]. reported that whole grains consumption was associated with decreased gastric risk. In 2019, Tonghua Wang et al. reported that whole grains consumption can reduce 13\% risk of gastric cancer [54]. In 2018,Rachna Khosla et al. [55]. reported that the association between whole-grains foods and decreased esophageal cancer risk has been seen.

Whole grains may influence cancer risk through a variety of mechanisms. First, whole grains are rich in a variety of phytochemicals, and these bioactive components offer potential benefits in reducing cancer [56-58]. Second, whole grains are an important source of dietary fiber. Dietary fiber can increase the volume of feces and shorten the transit time of the intestines, thereby diluting carcinogens and reducing their absorption in the intestinal epithelium. Dietary fiber can also be fermented in the colon into short chain fatty acids including butyrate. Butyrate is the fuel of choice for mucosal cells and has the potential to promote apoptosis and anti-tumor, thereby reducing tumor growth. They also lower the intestinal $\mathrm{pH}$, thereby reducing the solubility of free bile acids and reducing their carcinogenic activity. In addition, dietary fiber can remove nitrite in the stomach and reduce the concentration of nitroso compounds under strong acid conditions. Nitrate will increase the risk of gastric cancer [16, 59, 60]. Third, Consumption of whole grains has been proven to reduce the risk of obesity and improve metabolic disorders, and it can reduce risk of cancer [59, 61-64]. Fourth, whole grains have antioxidant and anti-inflammatory properties and it can improves blood sugar response and reduces insulin resistance, thereby reducing the risk of cancer [65-68].

Due to the difference of pathological location and etiology between colorectal, gastric and esophageal cancers, we did not conduct the subgroup analysis, sensitivity analysis and publication bias of whole grains intake and overall digestive tract cancer risk. In the meta-analysis of whole grains intake and colorectal cancer risk, we found a slight heterogeneity, and subgroup analysis was performed to find the source of heterogeneity. When subgroup analysis based on sex, geographic location, publication year and whether adjust for energy intake, no statistically significant heterogeneity was found in the studies of women, studies of Europe, studies of publication year before 2010 and studies of adjustment for energy; suggesting that sex, geographic location, publication year and whether adjust for energy intake 
may be a potential source of heterogeneity. In the metaanalysis of gastric cancer, there is significant heterogeneity. When subgroup analysis based on the study design showed that the heterogeneity was not significant in the cohort study,but the heterogeneity was still significant in the case-control study. This may be due to the recall bias and selection bias in case-control studies. In addition, the number of cohort studies is limited. Therefore, more cohort studies are needed to adequately adjust for potential confounders. Due to the significant publication bias of whole grains intake and gastric cancer risk, the association of whole grains and gastric cancer should be more cautious to interpret. In addition, we did not perform the subgroup analysis of whole grains and esophagus cancer risk because there was no statistically significant heterogeneitys.

There were limitations to our meta-analysis that should be considered. First, this study lacks high quality epidemiological studies. Due to the differences in methods for assessing whole-grains intake, we are unable to perform a meta-analysis of dose-response. Second, differences in the definitions of whole grains and in the categories of whole grains foods among studies might also be another possible source of heterogeneity. Third, there was high heterogeneity and publication bias in the analysis of whole grains and gastric. The existence of heterogeneity and publication bias makes it more cautious to interpret the results of this meta-analysis. Fourth, the included studies are mainly from Europe and America, lacking research in other regions. Finally, only published studies were included in the meta-analysis, the limitation of possible publication bias should be taken into consideration.

\section{Conclusion}

In conclusion, intake of higher whole grains can reduce the risk of colorectal cancer, gastric cancer and esophageal cancer. However, it should be more cautious to interpret the association of whole grains and gastric cancer because there is a high heterogeneity and significant publication bias. More high-quality study is needed in the future to clarify dose-response relationships and to assess the relationship between whole grains and digestive tract cancer.

\section{Abbreviations}

RR: Relative risk; Cl: Confidence interval; ORs: Odds ratios; NOS: Newcastle Ottawa Scale; CRC: Colorectal cancer; GC: Gastric Cancer; EC: Esophageal; ESCC: Esophageal Squamous Cell Cancer

\section{Acknowledgements}

Not applicable.

\section{Authors' contributions}

$L C, X Z$ and XW contributed to the conception and design of the study. YT, $X G$ and $X W$ conducted the literature search and data extraction. $L C, X Z$ and XWi performed the statistical analyses. XZ, XW, YT and XG drafted the manuscript. YG and JF supervised the study. All authors contributed to revisions of the article. All authors approved the final version of the article.

\section{Funding}

The present study was financially supported by the National Natural Science Foundation of China (81402670).

\section{Availability of data and materials}

The tables and figures supporting the conclusions of this article are included within the article.

\section{Ethics approval and consent to participate}

Not applicable.

\section{Consent for publication}

Not applicable.

\section{Competing interests}

The authors declare that they have no competing interests.

\section{Author details}

${ }^{1}$ Department of Nutrition and Food Hygiene, College of Public Health, Zhengzhou University, 100 Kexue Avenue, Zhengzhou 450001, Henan, China. ${ }^{2}$ Nursing College of Henan University of Chinese Medicine, Zhengzhou, Henan, China.

Received: 27 November 2019 Accepted: 22 April 2020

Published online: 03 June 2020

\section{References}

1. Bray F, Ferlay J, Soerjomataram I, Siegel RL, Torre LA, Jemal A. Global cancer statistics 2018: GLOBOCAN estimates of incidence and mortality worldwide for 36 cancers in 185 countries. CA Cancer J Clin. 2018(68):394-424.

2. Islami F, Goding Sauer A, Miller KD, Siegel RL, Fedewa SA, Jacobs EJ, McCullough ML, Patel AV, Ma J, Soerjomataram I, et al. Proportion and number of cancer cases and deaths attributable to potentially modifiable risk factors in the United States. CA Cancer J Clin. 2018;68:31-54.

3. Anand P, Kunnumakara AB, Sundaram C, Harikumar KB, Tharakan ST, Lai OS, Sung BY, Aggarwal BB. Cancer is a preventable disease that requires major lifestyle changes. Pharm Res. 2008;25:2097-116.

4. Song MY, Garrett WS, Chan AT. Nutrients, foods, and colorectal Cancer prevention. Gastroenterology. 2015;148:1244-U1217.

5. Vial M, Grande L, Pera M. Epidemiology of adenocarcinoma of the esophagus, gastric cardia, and upper gastric third. Recent Results Cancer Res. 2010;182:1-17.

6. Vieira AR, Abar L, Chan DSM, Vingeliene S, Polemiti E, Stevens C, Greenwood D, Norat T. Foods and beverages and colorectal cancer risk: a systematic review and meta-analysis of cohort studies, an update of the evidence of the WCRF-AICR continuous update project. Ann Oncol. 2017;28: 1788-802.

7. Jones JM, Pena RJ, Korczak R, Braun HJ. Carbohydrates, grains, and wheat in nutrition and health: an overview part I. role of carbohydrates in health. Cereal Foods World. 2015;60:224-33.

8. Flight I, Clifton P. Cereal grains and legumes in the prevention of coronary heart disease and stroke: a review of the literature. Eur J Clin Nutr. 2006;60: $1145-59$.

9. Kyro C, Tjonneland A. Whole grains and public health. BMJ. 2016;353:i3046.

10. van der Kamp JW, Poutanen K, Seal CJ, Richardson DP. The HEALTHGRAIN definition of 'whole grain'. Food Nutr Res. 2014;58.

11. Seal CJ, Brownlee IA. Whole-grain foods and chronic disease: evidence from epidemiological and intervention studies. Proc Nutr Soc. 2015;74:313-9.

12. Wu HY, Flint AJ, Qi QB, van Dam RM, Sampson LA, Rimm EB, Holmes MD, Willett WC, Hu FB, Sun Q. Association between dietary whole grain intake and risk of mortality two large prospective studies in US men and women. JAMA Intern Med. 2015:175:373-84.

13. Aune D, Keum N, Giovannucci E, Fadnes LT, Boffetta P, Greenwood DC, Tonstad S, Vatten $L$, Riboli E, Norat T. Whole grain consumption and risk of cardiovascular disease, cancer, and all cause and cause specific mortality: systematic review and dose-response meta-analysis of prospective studies. BMJ. 2016;353. 
14. Aune $D$, Norat $T$, Romundstad $P$, Vatten $L$. Whole grain and refined grain consumption and the risk of type 2 diabetes: a systematic review and doseresponse meta-analysis of cohort studies. Eur J Epidemiol. 2013;28:845-58.

15. Johnsen NF, Frederiksen K, Christensen J, Skeie G, Lund E, Landberg R, Johansson I, Nilsson LM, Halkjaer J, Olsen A, et al. Whole-grain products and whole-grain types are associated with lower all-cause and cause-specific mortality in the Scandinavian HELGA cohort. Br J Nutr. 2015;114:608-23.

16. Aune D, Chan DSM, Lau R, Vieira R, Greenwood DC, Kampman E, Norat T. Dietary fibre, whole grains, and risk of colorectal cancer: systematic review and dose-response meta-analysis of prospective studies. BMJ. 2011;343.

17. Jacobs DR Jr, Marquart L, Slavin J, Kushi LH. Whole-grain intake and cancer: an expanded review and meta-analysis. Nutr Cancer. 1998;30:85-96.

18. McCullough ML, Robertson AS, Chao A, Jacobs EJ, Stampfer MJ, Jacobs DR, Diver WR, Calle EE, Thun MJ. A prospective study of whole grains, fruits, vegetables and colon cancer risk. Cancer Causes Control. 2003;14:959-70.

19. McCarl M, Harnack L, Limburg PJ, Anderson KE, Folsom AR. Incidence of colorectal cancer in relation to glycemic index and load in a cohort of women. Cancer Epidemiol Biomark Prev. 2006;15:892-6.

20. Lissowska J, Gail MH, Pee D, Groves FD, Sobin LH, Nasierowska-Guttmejer A Sygnowska E, Zatonski W, Blot WJ, Chow WH. Diet and stomach cancer risk in Warsaw, Poland. Nutr Cancer Int J. 2004;48:149-59.

21. Kasum CM, Jacobs DR Jr, Nicodemus K, Folsom AR. Dietary risk factors for upper aerodigestive tract cancers. Int J Cancer. 2002;99:267-72.

22. Margulis AV, Pladevall M, Riera-Guardia N, Varas-Lorenzo C, Hazell L, Berkman ND, Viswanathan M, Perez-Gutthann S. Quality assessment of observational studies in a drug-safety systematic review, comparison of two tools: the Newcastle-Ottawa scale and the RTI item bank. Clin Epidemiol. 2014;6:359-68

23. Peters RK, Garabrant DH, Yu MC, Mack TM. A case-control study of occupational and dietary factors in colorectal cancer in young men by subsite. Cancer Res. 1989;49:5459-68.

24. Centonze S, Boeing H, Leoci C, Guerra V, Misciagna G. Dietary habits and colorectal cancer in a low-risk area. Results from a population-based casecontrol study in southern Italy. Nutr Cancer. 1994;21:233-46.

25. Slattery ML, Potter JD, Coates A, Ma KN, Berry TD, Duncan DM, Caan BJ. Plant foods and colon cancer: an assessment of specific foods and their related nutrients (United States). Cancer Causes Control. 1997;8:575-90.

26. Wu K, Hu FB, Fuchs C, Rimm EB, Willett WC, Giovannucci E. Dietary patterns and risk of colon cancer and adenoma in a cohort of men (United States). Cancer Causes Control. 2004;15:853-62.

27. Larsson SC, Giovannucci E, Bergkvist L, Wolk A. Whole grain consumption and risk of colorectal cancer: a population-based cohort of 60000 women. Br J Cancer. 2005;92:1803-7.

28. Schatzkin A, Mouw T, Park Y, Subar AF, Kipnis V, Hollenbeck A, Leitzmann MF, Thompson FE. Dietary fiber and whole-grain consumption in relation to colorectal cancer in the NIH-AARP diet and health study. Am J Clin Nutr. 2007:85:1353-60.

29. Williams CD, Satia JA, Adair LS, Stevens J, Galanko J, Keku TO, Sandler RS. Dietary patterns, food groups, and rectal Cancer risk in whites and AfricanAmericans. Cancer Epidemiol Biomark Prev. 2009;18:1552-61.

30. Egeberg R, Olsen A, Loft S, Christensen J, Johnsen NF, Overvad K, Tjonneland A. Intake of wholegrain products and risk of colorectal cancers in the diet, Cancer and health cohort study. Br J Cancer. 2010;103:730-4.

31. Fung TT, Hu FB, Wu KN, Chiuve SE, Fuchs CS, Giovannucci E. The Mediterranean and dietary approaches to stop hypertension (DASH) diets and colorectal cancer. Am J Clin Nutr. 2010;92:1429-35.

32. Kyro C, Skeie G, Loft S, Landberg R, Christensen J, Lund E, Nilsson LM, Palmqvist R, Tjonneland A, Olsen A. Intake of whole grains from different cereal and food sources and incidence of colorectal cancer in the Scandinavian HELGA cohort. Cancer Causes Control. 2013;24:1363-74.

33. Abu Mweis SS, Tayyem RF, Shehadah I, Bawadi HA, Agraib LM, Bani-Hani KE, Al-Jaberi T, Al-Nusairr M. Food groups and the risk of colorectal cancer: results from a Jordanian case-control study. Eur J Cancer Prev. 2015:24:313-20.

34. Tayyem RF, Bawadi HA, Shehadah I, Agraib LM, Al-Awwad NJ, Heath DD, Bani-Hani KE. Consumption of whole grains, refined cereals, and legumes and its association with colorectal Cancer among Jordanians. Integr Cancer Ther. 2016:15:318-25.

35. Angelo SN, Lourenco GJ, Magro DO, Nascimento H, Oliveira RA, Leal RF, Ayrizono MDS, Fagundes JJ, Coy CSR, Lima CSP. Dietary risk factors for colorectal cancer in Brazil: a case control study. Nutr J. 2016;15.
36. Bakken T, Braaten T, Olsen A, Kyro C, Lund E, Skeie G. Consumption of whole-grain bread and risk of colorectal Cancer among Norwegian women (the NOWAC study). Nutrients. 2016;8

37. Um CY, Campbell PT, Carter B, Wang Y, Gapstur SM, ML MC. Association between grains, gluten and the risk of colorectal cancer in the Cancer Prevention Study-\|l Nutrition Cohort. Eur J Nutr. 2019.

38. He XS, Wu KN, Zhang XH, Nishihara R, Cao Y, Fuchs CS, Giovannucci EL, Ogino S, Chan AT, Song MY. Dietary intake of fiber, whole grains and risk of colorectal cancer: an updated analysis according to food sources, tumor location and molecular subtypes in two large US cohorts. Int J Cancer. 2019; 145:3040-51.

39. La Vecchia C, Decarli A, Negri E, Parazzini F. Epidemiological aspects of diet and cancer: a summary review of case-control studies from northern Italy. Oncology. 1988;45:364-70.

40. Wu-Williams AH, Yu MC, Mack TM. Life-style, workplace, and stomach cancer by subsite in young men of Los Angeles County. Cancer Res. 1990;50:2569-76.

41. Boeing $H$, Frentzel-Beyme R, Berger $M$, Berndt V, Gores W, Korner M, Lohmeier R, Menarcher A, Mannl HF, Meinhardt M, et al. Case-control study on stomach cancer in Germany. Int J Cancer. 1991;47:858-64.

42. Boeing $H$, Jedrychowski W, Wahrendorf J, Popiela T, Tobiasz-Adamczyk B, Kulig A. Dietary risk factors in intestinal and diffuse types of stomach cancer: a multicenter case-control study in Poland. Cancer Causes Control. 1991;2: 227-33.

43. Jedrychowski W, Boeing H, Popiela T, Wahrendorf J, Tobiasz-Adamczyk B, Kulig J. Dietary practices in households as risk factors for stomach cancer: a familial study in Poland. Eur J Cancer Prev. 1992;1:297-304.

44. Hansson LE, Nyren O, Bergstrom R, Wolk A, Lindgren A, Baron J, Adami HO. Diet and risk of gastric cancer. A population-based case-control study in Sweden. Int J Cancer. 1993:55:181-9.

45. Munoz SE, Ferraroni M, La Vecchia C, Decarli A. Gastric cancer risk factors in subjects with family history. Cancer Epidemiol Biomark Prev. 1997;6:137-40.

46. Chatenoud L, La Vecchia C, Franceschi S, Tavani A, Jacobs DR Jr, Parpinel MT, Soler M, Negri E. Refined-cereal intake and risk of selected cancers in Italy. Am J Clin Nutr. 1999;70:1107-10.

47. McCullough ML, Robertson AS, Jacobs EJ, Chao A, Calle EE, Thun MJ. A prospective study of diet and stomach cancer mortality in United States men and women. Cancer Epidemiol Biomark Prev. 2001;10:1201-5.

48. Levi F, Pasche C, Lucchini F, Chatenoud L, Jacobs DR Jr, La Vecchia C. Refined and whole grain cereals and the risk of oral, oesophageal and laryngeal cancer. Eur J Clin Nutr. 2000;54:487-9.

49. Chen HL, Ward MH, Graubard BI, Heineman EF, Markin RM, Potischman NA, Russell RB, Weisenburger DD, Tucker KL. Dietary patterns and adenocarcinoma of the esophagus and distal stomach. Am J Clin Nutr. 2002;75:137-44

50. Jessri M, Rashidkhani B, Hajizadeh B, Jacques PF. Adherence to Mediterranean-style dietary pattern and risk of esophageal squamous cell carcinoma: a case-control study in Iran. J Am Coll Nutr. 2012;31:338-51.

51. Sewram V, Sitas F, O'Connell D, Myers J. Diet and esophageal cancer risk in the eastern Cape Province of South Africa. Nutr Cancer. 2014;66:791-9.

52. Skeie $G$, Braaten $T$, Olsen A, Kyro C, Tjonneland A, Landberg R, Nilsson LM, Wennberg M, Overvad K, Asli LA, et al. Intake of whole grains and incidence of oesophageal cancer in the HELGA cohort. Eur J Epidemiol. 2016:31:405-14.

53. Xu YJ, Yang J, Du L, Li K, Zhou Y. Association of whole grain, refined grain, and cereal consumption with gastric cancer risk: a meta-analysis of observational studies. Food Sci Nutr. 2019;7:256-65.

54. Wang TH, Zhan R, Lu J, Zhong L, Peng XJ, Wang M, Tang SH. Grain consumption and risk of gastric cancer: a meta-analysis. Int J Food Sci Nutr. 2019.

55. Sardana RK, Chhikara N, Tanwar B, Panghal A. Dietary impact on esophageal cancer in humans: a review. Food Funct. 2018;9:1967-77.

56. Wiseman M. The second World Cancer Research Fund/American Institute for Cancer Research expert report. Food, nutrition, physical activity, and the prevention of cancer: a global perspective. Proc Nutr Soc. 2008;67:253-6.

57. Oh H, Kim H, Lee DH, Lee A, Giovannucci EL, Kang SS, Keum N. Different dietary fibre sources and risks of colorectal cancer and adenoma: a doseresponse meta-analysis of prospective studies. Br J Nutr. 2019;122:605-15.

58. Idehen E, Tang Y, Sang SM. Bioactive phytochemicals in barley. J Food Drug Anal. 2017;25:148-61.

59. Borneo R, Leon AE. Whole grain cereals: functional components and health benefits. Food Funct. 2012;3:110-9. 
60. Makarem N, Nicholson JM, Bandera EV, McKeown NM, Parekh N. Consumption of whole grains and cereal fiber in relation to cancer risk: a systematic review of longitudinal studies. Nutr Rev. 2016;74:353-73.

61. Makarem N, Bandera EV, Lin Y, McKeown NM, Hayes RB, Parekh N. Associations of whole and refined grain intakes with adiposity-related Cancer risk in the Framingham offspring cohort (1991-2013). Nutr Cancer Int J. 2018;70:776-86.

62. Shahidi $F$, Chandrasekara A. Millet grain phenolics and their role in disease risk reduction and health promotion: a review. J Funct Foods. 2013;5:570-81.

63. Seo CR, Yi B, Oh S, Kwon SM, Kim S, Song NJ, Cho JY, Park KM, Ahn JY Hong JW, et al. Aqueous extracts of hulled barley containing coumaric acid and ferulic acid inhibit adipogenesis in vitro and obesity in vivo. J Funct Foods. 2015;12:208-18.

64. Luthria DL, Lu YJ, John KMM. Bioactive phytochemicals in wheat: extraction, analysis, processing, and functional properties. J Funct Foods. 2015;18:910-25.

65. Roberts DL, Dive C, Renehan AG. Biological mechanisms linking obesity and Cancer risk: new perspectives. Annu Rev Med. 2010;61:301-16.

66. Shikata K, Ninomiya T, Kiyohara Y. Diabetes mellitus and cancer risk: review of the epidemiological evidence. Cancer Sci. 2013;104:9-14.

67. Kim H, Stote KS, Behall KM, Spears K, Vinyard B, Conway JM. Glucose and insulin responses to whole grain breakfasts varying in soluble fiber, betaglucan: a dose response study in obese women with increased risk for insulin resistance. Eur J Nutr. 2009;48:170-5.

68. Samra R, Anderson GH. Insoluble cereal fiber reduces appetite and shortterm food intake and glycemic response to food consumed 75 min later by healthy men. Am J Clin Nutr. 2007:86:972-9.

\section{Publisher's Note}

Springer Nature remains neutral with regard to jurisdictional claims in published maps and institutional affiliations.

Ready to submit your research? Choose BMC and benefit from:

- fast, convenient online submission

- thorough peer review by experienced researchers in your field

- rapid publication on acceptance

- support for research data, including large and complex data types

- gold Open Access which fosters wider collaboration and increased citations

- maximum visibility for your research: over $100 \mathrm{M}$ website views per year

At $\mathrm{BMC}$, research is always in progress.

Learn more biomedcentral.com/submissions 